Efficient $\mathrm{Vol} 1$ (3) (2018): 260-269 DOI: https://doi.org/10.15294/efficient.vii3.27871
$\begin{gathered}\text { Indonesian Journal of Development Economics } \\ \text { http: journal.unnes.ac.id/sju/index.php/efficient }\end{gathered}$

\title{
Strategi Pengembangan Objek Wisata di Kabupaten Pati
}

\section{Fitrilia Ratnasari}

\author{
Jurusan Ekonomi Pembangunan, Fakultas Ekonomi, Universitas Negeri Semarang
}

Permalink/DOI: https://doi.org/10.15294/efficient.vii3.27871

Received: April 2018; Accepted: July 2018 ; Published: October 2018

\begin{abstract}
The objectives of this research are (1) to identify the profile and management system of tourism object in Pati Regency, (2) to identify the internal and external factors of tourism development in Pati Regency, (3) Prepare the development strategy of tourism object in Pati Regency. Data analysis technique using SWOT The result of the research shows that (1) the tourism object profile in Pati Regency has great potential to be a tourist place that can bring many visitors with management system that need to be improved in order to establish good relationship between the Tourism Office and the management of the tourism object. (2) Internal factors that are owned by tourism object such as tourist attraction, hospitality, facilities, promotion and capital. While the external factors that are owned by tourism are competitiveness of tourism object, community life style, government support, innovation, and accommodation. (3) Strategy of tourism development in Pati Regency based on SWOT is the development of potential in each tourism object, maintenance and addition of facilities in tourism object, as well as increasing cooperation with private parties and investors.
\end{abstract}

\section{Keywords: Development Strategy, Tourism Object.}

\section{Abstrak}

Tujuan dari penelitian ini adalah (1) mengidentifikasi profil dan sistem pengelolaan obyek wisata di Kabupaten Pati, (2) Mengidentifikasi faktor internal dan eksternal pengembangan obyek wisata di Kabupaten Pati, (3) Menyusun strategi pengembangan obyek wisata di Kabupaten Pati. Teknik analisis data menggunakan SWOT. Hasil penelitian menunjukkan bahwa (1) profil obyek wisata di Kabupaten Pati memiliki potensi yang sangat besar untuk dijadikan tempat wisata yang mampu mendatangkan banyak pengunjung dengan sistem pengelolaan yang perlu ditingkatkan agar menjalin hubungan yang baik antara Dinas Pariwisata dan pengelola obyek wisata. (2) Faktor internal yang dimiliki obyek wisata antara lain daya tarik wisata, keramahtamahan, fasilitas, promosi dan modal. Sedangkan faktor eksternal yang dimiliki obyek wisata adalah daya saing obyek wisata, gaya hidup masyarakat, dukungan pemerintah, inovasi, serta akomodasi. (3) Strategi pengembangan obyek wisata di Kabupaten Pati berdasarkan SWOT adalah pengembangan potensi di masing-masing obyek wisata, pemeliharaan dan penambahan fasilitas di obyek wisata, serta meningkatkan kerjasama dengan pihak swasta maupun investor.

\section{Kata Kunci: Strategi Pembangunan, Objek Wisata}

How to Cite: Ratnasari, F. (2018). Strategi Pengembangan Objek Wisata di Kabupaten Pati. EFFICIENT Indonesian Journal of Development Economics, 1(3), 260-269. https://doi.org/10.15294/efficient.vii3.27871

(C) 2018 Semarang State University. All rights reserved

Alamat Korespondensi : ISSN

Alamat: Gedung L2 Lantai 2 FE Unnes

Kampus Sekaran, Gunungpati, Semarang, 50229

E-mail : efficientjournal@gmail.com 


\section{PENDAHULUAN}

Berdasarkan Peraturan Pemerintah Republik Indonesia Nomor 50 Tahun 2011, yang dimaksud kepariwisataan adalah keseluruhan kegiatan yang terkait dengan pariwisata dan bersifat multidimensi serta multidisiplin yang muncul sebagai wujud kebutuhan setiap orang dan negara serta interaksi antara wisatawan dan masyarakat setempat, sesama wisatawan, pemerintah, pemerintah daerah, dan pengusaha. Pariwisata juga merupakan komoditas yang dibutuhkan oleh setiap individu karena aktivitas berwisata bagi seseorang (individu) dapat meningkatkan daya kreatif, menghilangkan kejenuhan kerja, relaksasi, berbelanja, bisnis, mengetahui peniggalan sejarah dan budaya suatu etnik tertentu, kesehatan dan pariwisata spiritualisme. Provinsi Jawa Tengah terletak di posisi strategis dalam penyelenggaraan kegiatan kepariwisataan dan kebudayaan di Indonesia. Jawa Tengah yang memiliki 29 Kabupaten dan 6 Kota. Pariwisata di Jawa Tengah merupakan sektor unggulan dan sektor yang mampu menciptakan multiplier effect. Dilihat dari kekayaan Jawa Tengah di bidang pariwisata dan kebudayaan, seharusnya Jawa Tengah dapat menjadi sasaran pariwisata baik wisatawan nusantara maupun mancanegara. Adapun 15 besar data kunjungan wisatawan di Provinsi Jawa Tengah dapat dilihat pada tabel 1.

Dari tabel 1 dapat dilihat bahwa pendapatan sektor pariwisata di Jawa Tengah bersifat fluktuasi dari tahun 2011 sampai dengan 2015. Rata-rata penurunan pendapatan pada $10 \mathrm{Kab} / \mathrm{Kota}$ dengan pendapatan terendah terjadi pada tahun
2013. Kabupaten Pati memiliki pendapatan sektor pariwisata terendah 35 (tiga puluh lima) Kabupaten / Kota di Jawa Tengah dalam kurun waktu 5 (lima) tahun terakhir dari tahun 2011-2015, penurunan pendapatan paling rendah di sektor pariwisata terjadi pada tahun 2013 yaitu dari 26.800 menjadi 17.800 (juta).

Dari tabel 2 dapat dilihat bahwa perkembangan objek wisata di Kabupaten Pati selalu mengalami peningkatan setiap tahunnya atau setiap tahun ada wisata baru yang bermunculan di Kabupaten Pati. Pada tahun 2011 hanya memiliki 3 objek wisata saja, tahun berikutnya yaitu 2012 menjadi 6 objek wisata, jumlah pertumbuhan objek wisata terbanyak di Kabupaten Pati pada tahun 2015 dengan jumlah objek wisata 10 dan jumlah kunjungan objek wisata tertinggi yaitu desa wisata talun dengan jumlah pengunjung mencapai 49.ooo. Walaupun begitu Kabupaten Pati memiliki pendapatan sektor pariwisata masih sangat rendah urutan ke 35 dari 35 Kab/Kota Jawa Tengah. Hasil observasi awal dilanjutkan dengan melakukan observasi ke objek wisata unggulan yang akan dibuatkan Perda retribusi secara resmi oleh pemerintah pada bulan Maret 2017. Keadaan di lapangan menunjukkan bahwa objek wisata tersebut sangat kurang dalam pengembangan, tidak jelas sistem pengelolaandengan belum terstrukuturnya pengelolaan objek wisata dapat dilihat fasilitas yang sangat minim seperti halnya toilet dan musholla tidak ada toilet dan mushola tidak ada di Objek Wisata Goa Wareh dan Bukit Pandang, kurangnya kios penjual makanan dan minuman untuk pengunjung di 4 objek wisata unggulan, keamanan yang kurang di 
sekitar objek wisata, kurangnya gazebo atau tempat duduk pengunjung, dan kurangnya wahana yang membuat para pengunjung nyaman berada di objek wisata.

Tabel 1. 1o Kab/Kota di Jawa Tengah yang Memiliki Pendapatan Sektor Pariwisata Terendah Tahun 2011-2015 (Juta)

\begin{tabular}{lllllll}
\hline & Kab/Kota & Tahun & & & \\
& & 2011 & 2012 & 2013 & 2014 & 2015 \\
\hline 1. & Kota Pekalongan & 659.165 & 871.828 & 924.172 & 889.757 & 1.081 .989 \\
2. & Kab. Brebes & 616.506 & 618.420 & 849.998 & 967.116 & 1.292 .006 \\
3. & Kab. Batang & 696.792 & 823.637 & 779.141 & 776.506 & 1.118 .909 \\
4. & Kab. Klaten & 801.512 & 984.076 & 728.238 & 892.121 & 732.902 \\
5. & Kota Tegal & 649.237 & 531.082 & 630.741 & 832.060 & 930.545 \\
6. & Kab. Kendal & 398.621 & 790.958 & 831.563 & 918.793 & 133.208 \\
7. & Kab. Blora & 275.200 & 659.881 & 243.827 & 573.310 & 262.967 \\
8. & Kab. Sukoharjo & 87.234 & 134.895 & 129.416 & 117.264 & 101.372 \\
9. & Kab. Salatiga & 75.348 & 82.793 & 83.769 & 252.185 & 31.080 \\
10. & Kab. Pati & 18.080 & 26.881 & 17.816 & 43.029 & 106.506 \\
\hline
\end{tabular}

Sumber : Dinas Pemuda, Olahraga, dan Pariwisata Jawa Tengah tahun 2011-2105

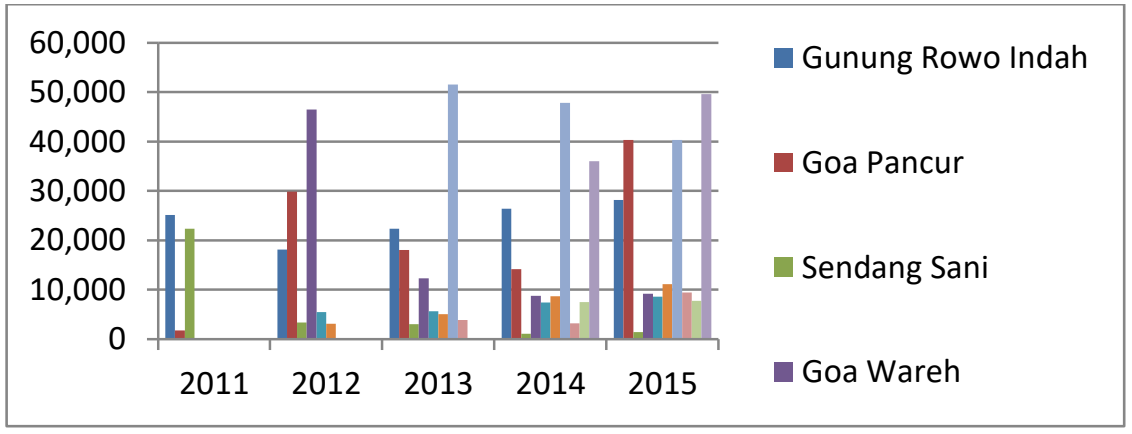

Gambar.1. 10 Kab/Kota di Jawa Tengah yang Memiliki Pendapatan Sektor Pariwisata Terendah Tahun 2011-2015 (Juta)

Sumber : Dinas Pemuda, Olahraga, dan Pariwisata Jawa Tengah tahun 2011-2015 


\section{METODE PENELITIAN}

Penelitian ini dilaksanakan pada Bulan Juli-Agustus 2017. Penelitian ini berlokasi di Kabupaten Pati. Data diperoleh dari Kantor Dinas Pariwisata Kabupaten Pati, Dinas Pariwisata Jawa Tengah untuk memperoleh data kunjungan wisatawan, fasilitas, serta kebijakan.

Pengumpulan data dengan melakukan observasi, kuesioner dan wawancaradengan teknik analisis data menggunakan SWOT yang sebagian besar dijaring melalui kuesioner.

\section{HASIL DAN PEMBAHASAN}

Obyek wisata yang dikelola oleh pemerintah Kabupaten Pati memiliki potensi yang bagus dan dapat dijadikan sebagai obyek wisata unggulan dan mendukung untuk meningkatkan pendapatan di sektor wisata, hanya saja masih perlu penambahan serta pemeliharaan fasilitas yang ada agar menambah kenyamanan pengunjung. Sistem pengelolaan obyek wisata di Kabupaten Pati adalah melalu POKDARWIS yang ada dilapangan melaporkan perkembangan kegiatan maupun pelaksanaan teknis di obyek wisata kepada UPTD, UPTD menampung semua perkembangan kegiatan maupun pelaksanaan teknis kegiatan yang ada di obyek wisata yang dikelola oleh Dinas Pariwisata Kabupaten Pati.

Selanjutnya melalui sub program, evaluasi, \& pelaporan memilah hasil dari pelaporan tersebut lalu di salurkan kepada bagian yang ada seperti bidang promosi, bidang kebudayaan, bidang usaha pariwisata sesuai dengan kebutuhan dan permasalahan di lapangan, selanjutnya kebijakan atau program dari sub bagian tadi diajukan kepada Kepala Dinas Pariwisata disetujui atau tidak. Jika kebijakan atau program tersebut disetujui oleh Kepala Dinas Pariwisata maka dilanjutkan untuk direalisasikan ke lapangan, tetapi jika kebijakan atau program tersebut tidak disetujui oleh Kepada Dinas Pariwisata maka akan direvisi kembali oleh sub-sub bidang yang menanganinya. Permasalahan yang sering terjadi adalah waktu yang terlalu lama samapai dengan realisasi ke lapangan sehingga POKDARWIS tidak hanya menggandalkan dari pemerintah saja melainkan juga berinovasi sendiri. Sistem pengelolaan obyek wisata di Kabupaten Pati adalah dengan Sistem pengelolaan obyek wisata di Kabupaten Pati adalah melalu POKDARWIS yang ada dilapangan melaporkan perkembangan kegiatan maupun pelaksanaan teknis di obyek wisata kepada UPTD, UPTD menampung semua perkembangan kegiatan maupun pelaksanaan teknis kegiatan yang ada di obyek wisata yang dikelola oleh Dinas Pariwisata Kabupaten Pati. Selanjutnya melalui sub program, evaluasi, \& pelaporan memilah hasil dari pelaporan tersebut lalu di salurkan kepada bagian yang ada seperti bidang promosi, bidang kebudayaan, bidang usaha pariwisata sesuai dengan kebutuhan dan permasalahan di lapangan, selanjutnya kebijakan atau program dari sub bagian tadi diajukan kepada Kepala Dinas Pariwisata disetujui atau tidak. Jika kebijakan atau program tersebut disetujui oleh Kepala Dinas Pariwisata maka dilanjutkan untuk direalisasikan ke lapangan, tetapi jika kebijakan atau program tersebut tidak 
disetujui oleh Kepada Dinas Pariwisata maka akan direvisi kembali oleh sub-sub bidang yang menanganinya. Permasalahan yang sering terjadi adalah waktu yang terlalu lama samapai dengan realisasi ke lapangan sehingga POKDARWIS tidak hanya menggandalkan dari pemerintah saja melainkan juga berinovasi sendiri.

\section{Fator Internal dan Eksternal Pengembangan Objek Wisata Di Kabupaten Pati}

Faktor internal dan eksternal pengembangan di Kabupaten Pati dibagi menjadi beberapa sub bagian. Faktor eksternal terdiri dari kekuatan dan kelemahan, faktor kekuatan pengembangan obyek wisata di Kabupaten Pati yaitu panorama alam yang indah, suasana obyek wisata yang memberikan kenyamanan, kebersihan di sekitar obyek wisata, harga tiket yang terjangkau, kondisi jalan yang baik, keramahan pengelola obyek wisata, dan letak obyek wisata yang strategis.

Faktor kelemahan pengembangan obyek wisata Kabupaten Pati yaitu promosi obyek wisata yang masih kurang, program pengembangan obyek wisata yang masih sederhana, kurangnya tenaga kerja profesional, keterbatasan anggaran untuk pengembangan obyek wisata, keamanan obyek wisata yang masih minim, Kabupaten Pati masih jauh dari pasar utama wisatawan. Sedangkan faktor eksternal terdiri dari peluang dan ancaman, faktor peluang pengembangan obyek wisata di Kabupaten Pati yaitu otonomi daerah, aksesbilitas yang mudah, adanya investasi, adanya inovasi, dan ikut serta dalam acara-acara event.
Faktor ancaman pengembangan obyek wisata di Kabupaten Pati yaitu berkembangnya obyek wisata lain, adanya kerusakan lingkungan, dan gaya hidup masyarakat modern.

\section{Strategi Pengembangan Objek Wisata Di Kabupaten Pati}

\section{Objek Wisata Gunung Rowo}

Analisis SWOT digunakan untuk merumuskan strategi dengan mengidentifikasi kekuatan, kelemahan, peluang, dan ancaman yang dimiliki objek wisata Waduk Gunung Rowo. Analisis ini didasarkan pada logika yang dapat memaksimalkan kekuatan dan peluang, serta secara bersama-sama dapat meminimalkan kelemahan dan ancaman. Berdasarkan perhitungan yang dilakukan melalui analisis SWOT, diperoleh nilai akhir dari kekuatan, kelemahan, peluang, dan ancaman, faktor internal sebesar 0,908 dan faktor eksternal sebesar 1.786.

Apabila hasil perhitungan tersebut dimasukan ke dalam Matrix Grand Strategy terlihat pengembangan objek wisata Waduk Gunung Rowo berada pada kuadran I, dimana objek wisata berada pada situasi yang menguntungkan karena memiliki kekuatan dan peluang yang lebih besar dari kelemahan dan ancamannya sehingga objek wisata Waduk Gunung Rowo dapat memanfaatkan kekuatan yang dimiliki untuk merebut peluang yang ada.

Strategi yang dapat diterapkan pada objek wisata ini adalah potensi yang ada di sekitar objek wisata Waduk Gunung Rowo yaitu penghasil kopi, selain itu ada budaya 
masyarakat sekitar yaitu larungan sedekah bumi. Melalui otonomi daerah dapat mengembangkan serta menggabungkan kebudayaan menjadi daya tarik pengunjung melalui event atau acara yang diadakan di objek wisata tersebut

Tabel 2. Matrik Faktor Internal dan Faktor Ekstenal Pengembangan

Objek Wisata di Kabupaten Pati

\begin{tabular}{|c|c|}
\hline Faktor Internal & Faktor Eksternal \\
\hline Kekuatan & Peluang \\
\hline Panorama alam yang indah, sejuk dan masih asri & Otonomi Daerah \\
\hline Suasana Objek Wisata yang memberikan Kenyamanan & Aksesbilitas yang mudah \\
\hline Kebersihan di Sekitar Objek Wisata & Adanya Investasi \\
\hline Harga Tiket yang Terjangkau & Adanya Inovasi \\
\hline Kondisi jalan yang baik & Ikut serta dalam berbagai bazaar atau \\
\hline Keramahan Pengelola Objek Wisata & pameran yang dilaksanakan baik dalam \\
\hline Letak Objek Wisata yang Strategis & lingkup regional maupun nasional \\
\hline Kelemahan & Ancaman \\
\hline Promosi Objek Wisata yang Masih Kurang & Berkembangnya Objek Wisata Lain \\
\hline Program Pengembangan Objek Wisata yang Masih & Adanya kerusakan lingkungan \\
\hline Sederhana & Gaya hidup masyarakat \\
\hline \multicolumn{2}{|l|}{ Kurangnya Tenaga Kerja Profesional dan Pengelolaan Objek } \\
\hline \multicolumn{2}{|l|}{ Wisata } \\
\hline \multicolumn{2}{|l|}{ Keterbatasan Anggaran untuk Biaya Pengembangan Objek } \\
\hline \multicolumn{2}{|l|}{ Wisata } \\
\hline \multicolumn{2}{|l|}{ Keamanan di Objek Wisata } \\
\hline \multicolumn{2}{|l|}{ Minimnya Sarana di Objek Wisata } \\
\hline Kabupaten Pati Masih Jauh Dari Pasar Utama Wisatawan & \\
\hline
\end{tabular}

Apabila hasil perhitungan tersebut

\section{Objek Wisata Bukit Naga Jolong}

Analisis SWOT digunakan untuk merumuskan strategi dengan mengidentifikasi kuatan, kelemahan, peluang, dan ancaman yang dimiliki objek wisata Bukit Naga Jolong. Analisis ini didasarkan pada logika yang dapat memaksimalkan kekuatan dan peluang, serta secara bersama-sama dapat meminimalkan kelemahan dan ancaman. Berdasarkan perhitungan yang dilakukan melalui analisis SWOT, diperoleh nilai akhir dari kekuatan, kelemahan, peluang, dan ancaman seperti terlihat pada tabel faktor internal sebesar 0,923 dan faktor eksternal sebesar 2.341. dimasukan ke dalam Matrix Grand Strategy terlihat pengembangan objek wisata Bukit Naga Jolong berada pada kuadran I, dimana objek wisata berada pada situasi yang menguntungkan karena memiliki kekuatan dan peluang yang lebih besar dari kelemahan dan ancamannya sehingga objek wisata Bukit Naga Jolong dapat memanfaatkan kekuatan yang dimiliki untuk merebut peluang yang ada. Strategi yang dapat diterapkan pada objek wisata ini adalah sarana transportasi dan akses yang mudah akan mempermudah para pengunjung ke objek wisata bukit naga jolong. Potensi yang ada di sekitar objek wisata Bukit Naga Jolong yaitu perkebunan 
kopi dan perkebunan buah naga, jeruk, serta melon. Melalui otonomi daerah dapat mengembangkan dengan menambah fasilitas pengunjung dengan petik buah sendiri, serta edukasi tentang tamanan kopi atau buah-buahan. Selain menambah jumlah kunjungan juga dapat sebagai pasar dari produk di lingkungan objek wisata itu sendiri.

\section{Objek Wisata Bukit Pandang}

Analisis SWOT digunakan untuk merumuskan strategi dengan mengidentifikasi kuatan, kelemahan, peluang, dan ancaman yang dimiliki objek wisata Bukit Pandang. Analisis ini didasarkan pada logika yang dapat memaksimalkan kekuatan dan peluang, serta secara bersama-sama dapat meminimalkan kelemahan dan ancaman. Berdasarkan perhitungan yang dilakukan melalui analisis SWOT, diperoleh nilai akhir dari kekuatan, kelemahan, peluang, dan ancaman seperti terlihat pada tabel faktor internal sebesar o,935 dan faktor eksternal sebesar 2,487.

Apabila hasil perhitungan tersebut dimasukan ke dalam Matrix Grand Strategy terlihat pengembangan objek wisata Bukit Pandang berada pada kuadran I, dimana objek wisata berada pada situasi yang menguntungkan karena memiliki kekuatan dan peluang yang lebih besar dari kelemahan dan ancamannya sehingga objek wisata Bukit Pandang dapat memanfaatkan kekuatan yang dimiliki untuk merebut peluang yang ada. Strategi yang dapat diterapkan di objek wisata ini adalah potensi yang ada di sekitar objek wisata Bukit Pandang yaitu keindahan Perbukitan Kendeng selain untuk melihat panorama alam dari ketinggian dengan menyediakan spot foto juga dapat dikembangakan wisata alam dengan menambah camping ground ataupun flying fox di area wisata dengan pemanfaatan investor untuk mendukung terlaksananya rencana tersebut. Selain menambah jumlah kunjungan juga dapat membuka lowongan pekerjaan maupun meningkatkan perekonomian di sekitar objek wisata.

\section{Objek Wisata Goa Wareh}

Analisis SWOT digunakan untuk merumuskan strategi dengan mengidentifikasi kuatan, kelemahan, peluang, dan ancaman yang dimiliki objek wisata Goa Wareh. Analisis ini didasarkan pada logika yang dapat memaksimalkan kekuatan dan peluang, serta secara bersamasama dapat meminimalkan kelemahan dan ancaman. Berdasarkan perhitungan yang dilakukan melalui analisis SWOT, diperoleh nilai akhir dari kekuatan, kelemahan, peluang, dan ancaman seperti terlihat pada tabel faktor internal sebesar 0,968 dan faktor eksternal sebesar 1,66. Apabila hasil perhitungan tersebut dimasukan ke dalam Matrix Grand Strategy terlihat pengembangan objek wisata Goa Wareh berada pada kuadran I, dimana objek wisata berada pada situasi yang menguntungkan karena memiliki kekuatan dan peluang yang lebih besar dari kelemahan dan ancamannya sehingga objek wisata Goa Wareh dapat memanfaatkan kekuatan yang dimiliki untuk merebut peluang yang ada. Strategi yang dapat diterapkan diobjek wisata ini adalah Objek wisata Goa Wareh di kelilingi oleh perkebunan tebu yang cukup luas dan bisa 
dibilang bahwa potensi produk yang dapat dikembangkan adalah tebu, pengolahan tebu dengan berbagai macam bentuk minuman dapat menjadi ciri khas dari desa di sekitar objek wisata dan dapat dijadikan oleh-oleh bagi pengunjung luar daerah yang sedang melakukan wisata. Penambahan fasilitas yang cukup memadai bagi pengunjung seperti ban dan pelampung untuk susur goa degan di pandu oleh guide masyarakat lokal maupun foto underwater, kamar mandi yang layak untuk pengunjung serta warung makan di sekitar objek wisata Goa Wareh.

\section{SIMPULAN}

Objek wisata memiliki potensi yang bagus akan tetapi masih perlu penambahan serta pemeliharaan fasilitas yang ada agar menambah kenyamanan pengunjung. Sistem pengelolaan obyek wisata di Kabupaten Pati adalah melalui POKDARWIS melaporkan pelaksanaan teknis di objek wisata kepada UPTD, UPTD menampung semua pelaksanaan teknis kegiatan yang ada di objek wisata yang dikelola oleh Dinas Pariwisata Kabupaten Pati. Selanjutnya melalui sub program, evaluasi, \& pelaporan memilah hasil dari pelaporan tersebut lalu di salurkan kepada bagian yang ada seperti bidang promosi, bidang kebudayaan, bidang usaha pariwisata sesuai dengan kebutuhan dan permasalahan di lapangan, selanjutnya kebijakan atau program dari sub bagian tadi diajukan kepada Kepala Dinas untuk disetujui atau tidak. Permasalahan yang sering terjadi adalah waktu yang terlalu lama sampai dengan realisasi ke lapangan.

Faktor internal dan eksternal pengembangan di Kabupaten yaitu panorama alam yang indah, suasana objek wisata yang memberikan kenyamanan, kebersihan di sekitar objek wisata, harga tiket yang terjangkau, kondisi jalan yang baik, keramahan pengelola objek wisata, dan letak objek wisata yang strategis. Promosi objek wisata yang masih kurang, program pengembangan objek wisata yang masih sederhana, kurangnya tenaga kerja profesional, keterbatasan anggaran untuk pengembangan objek wisata, keamanan objek wisata yang masih minim, Kabupaten Pati masih jauh dari pasar utama wisatawan Otonomi daerah, aksesbilitas yang mudah, adanya investasi, adanya inovasi, dan ikut serta dalam acara-acara event, berkembangnya objek wisata lain, adanya kerusakan lingkungan, dan gaya hidup masyarakat modern.

Strategi pengembangan objek wisata Waduk Gunung Rowo, Bukit Naga Jolong, Bukit Pandang, dan Goa Wareh berada pada strategi agresif., antara lain memanfaatkan potensi objek wisata yang dimiliki (panorama alam yang indah, suasana objek wisata yang nyaman, kebersihan objek wisata, harga tiket yang terjangkau, kondisi jalan yang baik, keramahan pengelola objek wisata, dan letak objek wisata yang strategis) dengan adanya otonomi daerah yang memberikan kewenangan kepada pemerintah daerah untuk mengelola potensi daerahnya masing-masing sesuai keinginan untuk berkembang menjadi lebih baik termasuk sektor pariwisatanya. produk dan permainan wisata yang baru didalam perkembangannya sehingga mampu menarik para pengunjung dan investor untuk ikut dalam mengembangkan objek wisata yang sudah ada atau membuat objek wisata baru, meningkatkan kerjasama dengan kelompok 
usaha atau objek wisata dan investasi terkait permodalan.

Pembenahan fasilitas objek wisata di Kabupaten Pati perlu dilakukan. Salah satunya dengan gencar melakukan promosi dan mengajak kerjasama dengan pihak swasta maupun investor untuk membantu dalam pengembangan objek wisata.

Pengelola objek wisata harus lebih mandiri aktif dalam mengenalkan objek wisata maupun potensi-potensi wisata kepada masyarakat luas melalui komunitas yang ada di Kabupaten Pati untuk meningkatkan jumlah kunjungan maupun mengenalkan Kabupaten Pati lebih lanjut kepada masyarakat luar daerah melalui pariwisata. Penambahan wahana wisata perahu untuk keliling waduk, permainan anak-anak di objek wisata Gunung Rowo, penambahan fasilitas di setiap objek wisata. Penambahan paket wisata untuk petik buah di objek wisata Bukit Naga Jolong. Inovasi wisata dengan adanya susur goa di Goa Wareh dan paket edukasi outbond untuk objek wisata Bukit Pandang.

\section{DAFTAR PUSTAKA}

Ariyanto. (2005). Ekonomi Pariwisata. Jakarta: Rineka Cipta.

Arikunto. (2006). Prosedur Penelitian Suatu Pendekatan Praktek. Jakarta : PT. Rineka Cipta.

Badan Pusat Statistik Kabupaten Pati.

Badan Pusat Statistik Provinsi Jawa Tengah

Buku Saku Kebudayaan Dan Pariwisata Kabupaten Pati 2016.

Darun. (2016). Strategi Pengembangan Objek Wisata Dan Kontribusinya Terhadap Penerimaan Retribusi Di Kabupaten Batang. Skripsi. Semarang: Fakultas Ekonomi UNNES.

Dinas Kebudayaan, Pariwisata, Pemuda, dan Olahraga Kabupaten Pati.
Dinas Pemuda, Olahraga, dan Pariwisata Jawa Tengah. 2011-2015. Pengunjung Wisata. Diakses tanggal 24 Februari, 2017.

Dinas Pemuda, Olahraga, dan Pariwisata Jawa Tengah. 2011-2015. Pendapatan Sektor Wisata. Diakses tanggal 24 Februari, 2017.

Fandeli, Mukhlison. (2000). Pengusahaan Ekowisata. UGM. Yogyakarta.

Fitriyani, Fauziah. (2017). Strategi Pengembangan Obyek Wisata Taman Rekreasi Pantai Kartini. Skripsi. Semarang : UNNES.

Fitriani, Hanifa. (2014). Strategi Pengembangan Desa Wisata Talun Melalui Model Pemberdayaan Masyarakat. Economics Development Analysis Journal

Freddy, Rangkuti. (2005). Analisis SWOT : Teknik Membedah Kasus Bisnis. Jakarta : PT. Gramedia.

Lovekaristy, Valentika Godis. (2014). Analisis Willingness To Pay Penguunjung Domestik Warisan Hidup Candi Borobudur dalam Upaya Pemeliharaan. Skripsi. Semarang : UNDIP.

Pendit, Nyoman S. 2006. Ilmu Pariwisata Sebuah Pengantar Perdana. Jakarta : Pradnya Paramita.

Peraturan Pemerintah Republik Indonesia Nomor 50 Tahun 2011 Tentang Pariwisata.

Pradikta, A. (2015). Strategi Pengembangan Obyek Wisata Waduk Gunungrowo Indah Dalam Upaya Meningkatkan Pendapatan Asli Daerah (PAD) Kabupaten Pati. Economics Development Analysis Journal.

Ramadhan, Dede Stya. (2016). Strategi Pengembangan Puri Maerakaca Terhadap Pendapatan Sektor Wisata. Economics Development Analysis Journal.

Sugiyono. (2016). Metode Penelitian Kuantitatif, Kualitatif dan R\&D. Bandung: Alfabeta.

Sammeng, Andi Mappi. (2001).Cakrawala Pariwisata. Jakarta : Balai Pustaka.

Undang Undang Republik Indonesia Nomor 19.Tahun 2009 Tentang Kepariwisataan.

Undang Undang Republik Indonesia No 32 Tahun 2004 Tentang Pemerintah Daerah.

Undang Undang Republik Indonesia No 23 Tahun 2014 Tentang Pemerintah Daerah.

Yoeti, Oka A. (2008). Perencanaan \& Pengembangan Pariwisata. Jakarta: PT Pradaya Paramita 


\section{LAMPIRAN}

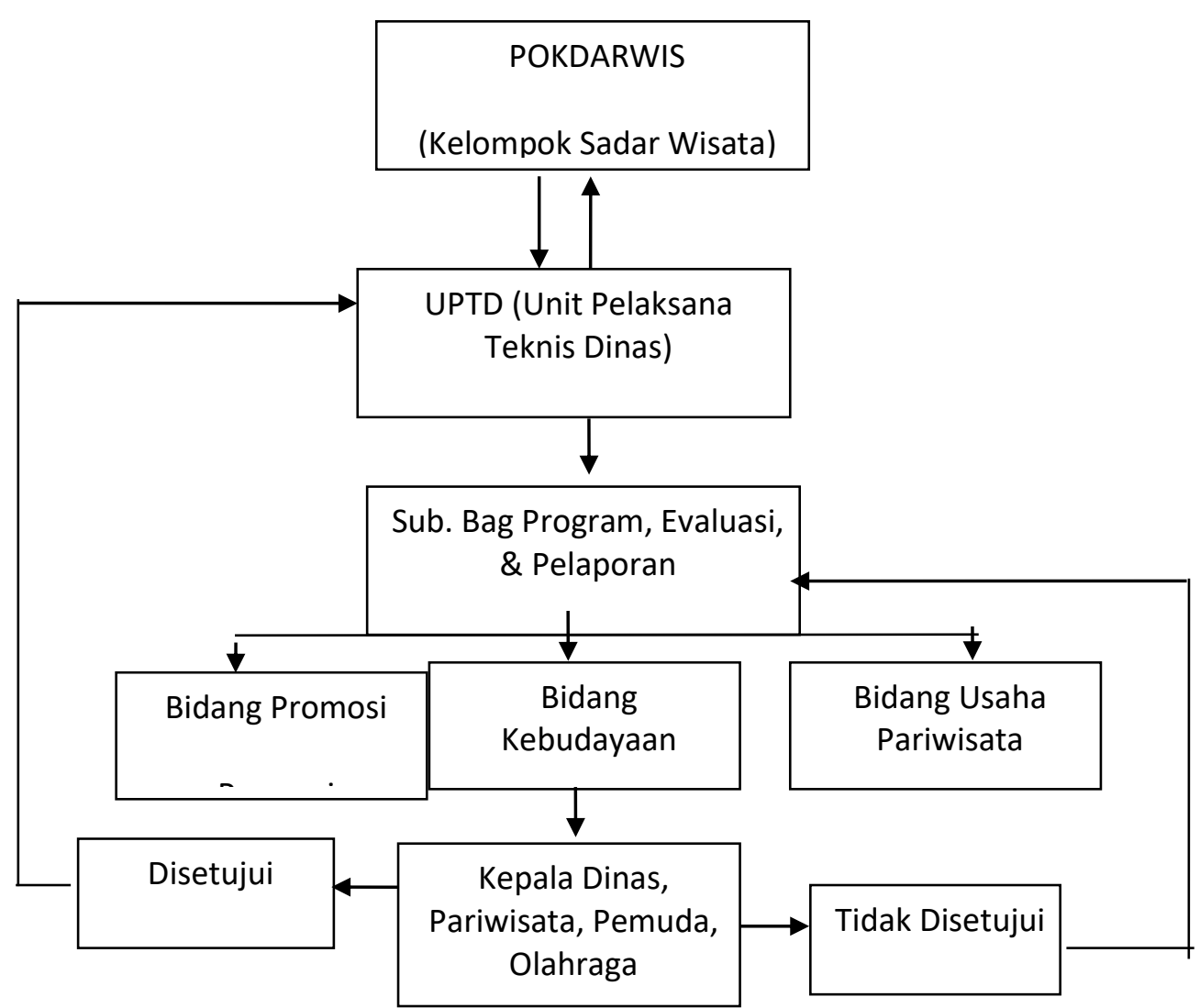

Gambar 2. Alur Pengelolaan Obyek Wisata Kabupaten Pati.

Sumber : Dinas Pariwisata, Pemuda, dan Olahraga Kabupaten Pati. 